Print ISSN: 2234-3040 / Online ISSN: 2234-3059

doi: 10.13106/eajbm.2014.vol5.no3.29.

[Field Research]

\title{
Country Analysis: Algeria
}

\author{
Quafaa Mehyaoul*
}

Received: Fbruary 10, 2015. Revised: July 15, 2015. Accepted: July 15, 2015.

\section{Abstract}

Purpose - The purpose of this country analysis is to examine its current state: economically, politically, legally, and ethically, and look at small and medium Algerian businesses to identify any issues that could hinder economic and business performance and growth.

Research Design, and Methodology - This is a case study, an analytical approach, which focuses on exploring and analyzing different aspects of Algeria.

Results - Since 2008, the Algerian economy has experienced a relative slowdown due to falling oil and gas prices and the economic recessions of its main trading partners, in particular, European countries. Algeria has still not managed to diversify its economy or establish competitive industrialization at the international level; it has had difficulty shifting from its economic dependence on hydrocarbons. Algerian businesses continue to face obstacles and constraints, penalized in their performance and prevented from success in a dense and competitive global marketplace.

Conclusion - The Algerian economy and Algerian businesses have shown positive performance and growth over the last few decades. However, issues exist that may hinder both business and economic progress in the future.

Keywords: Country Analysis, Algeria, Algerian Business and Economy.

JEL Classifications: A1, H3, K2, M2, O4.

\section{Country Overview}

Algeria or "People's Democratic Republic of Algeria" is a country in North Africa, which is part of the Maghreb (the eastern part of the Arab world). Its capital city is, "Algiers ". With a total area of $2,381,741 \mathrm{~km} 2$, it is both the largest country in

\footnotetext{
* Assistant Professor, Faculty of Economics, University of Oran, Algeria, E-mail:wafaa31000@yahoo.fr.
}

Africa, the Arab world and the Mediterranean coast (World Statistics, 2013). After 132 years of French colonization, Algeria gained its independence in July 5th, 1962. The total population is estimated to be $38,700,000$ in January 1st, 2014 (National Office of Statistics, 2014). The local currency is the «Dinar (DZD)». Externally, Algeria is the fourth largest economy of the African continent with a GDP of USD 207.8 billion (CIA World Factbook, 2012). Algeria is a member of the Organization of Petroleum Exporting Countries (OPEC) and Gas Exporting Countries Forum (GECF). It is one of the most important producers and exporters of natural gas (6th largest producer and 5th largest exporter) and oil (15th largest producer and 10th largest exporter) (CIA World Factbook, 2012). The hydrocarbons sector is the main source of income for the country $(37 \%$ of GDP, $97 \%$ of export revenues and $70 \%$ of fiscal revenues) (La Direction, 2013). Algeria also has large reserves of minerals: iron, gold, uranium, zinc, lead, phosphate, salt and coal. The main activities in the manufacturing sector: food-processing industry, textiles, chemicals, metals, building materials, mechanical, electrical and electronics industries. As for agriculture, it accounts for $10 \%$ of GDP and employs nearly $23 \%$ of the labor force (Ministry of Agriculture and Rural Development, 2012). The main crops are wheat, barley, oats, citrus fruits, wine growing, olives, tobacco and dates. Algeria is also a major producer of cork and an important cattle breeder.

\section{Algerian Economy Development}

At independence in 1962, the Algerian government has opted for a socialist centrally planned economy. The initial objectives were to give Algeria independence economically by recoveringnational resources. Indeed, the period 1962-1971 was marked by the nationalization of the economy key sectors (nationalization of mines in 1966 and hydrocarbons in 1971), the banking sector and the creation of public companies (Pironet, 2006). Later, Algeria has launched a major economic development project; the Algerian development strategy was characterized by the exploitation of mineral resources, hydrocarbons in particular, the creation of an industrial fabric and developing economic and social infrastructure. An extensive investment program was im- 
plemented as part of successive development plans, funded in large part by oil and gas revenues (Bali, 1993).

In the 1980s, the Algerian economy has experienced significant difficulties, the 1986 oil shock (oil prices have fallen by $40 \%$ ) was a crippling blow to a system built solely on the performance of the hydrocarbons sector. Quickly the whole economy is paralyzed: falling export revenues, heavy foreign debt, high unemployment rate, and soaring inflation (Bali, 1993).

By the end of 80s, Algeria has embarked on an economic reform process, the transition from a socialist economy to a market economy. In 1994, Algeria has negotiated a structural adjustments program with the International Monetary Fund (IMF) and the World Bank, the program included: devaluation of the Algerian dinar, liberalization of prices (removing price controls), foreign trade liberalization, openness to Foreign Direct Investment (FDI), rescheduling of foreign debt, privatization of all or part of state-owned enterprises, liberalizing the banking sector and creating private banks (Bali, 1993).

Structural adjustments and macroeconomic stabilization efforts undertaken between 1994 and 1999 (resumption of international agreements negotiation and signing of the Association Agreement with the $\mathrm{EU}$ in 2002, the early repayment of foreign debt, rising in oil prices, the public companies privatization program) have enabled the Algerian economy to resume growth. From 2000, the Algerian economy is characterized by a good macro-financial performance and has a very favorable economic situation both internally and externally: an average GDP growth rate of $3.5 \%$ to $4 \%$ between 2000 and 2013 , the reduction of foreign debt at just over USD 300 million compared to USD 30 billion in the late 90s, exports revenues reached USD 63.5 billion in 2013 against USD 21.1 billion in 2000, what has substantially enhanced the trade balance surplus, foreign exchange reserves increased from USD 11.9 billion in 2000 to more than USD 194 billion in 2013, inflation controlled at $3.3 \%$ by the end of 2013 and an unemployment rate of $9.8 \%$ against $29.8 \%$ in 2000. The IMF has ranked Algeria as the least indebted country in the MENA region in 2012 and the second largest holder of foreign exchange reserves after Saudi Arabia (Algeria Media Service).

It is worth noting that the Algerian economy has not been directly affected by the impact of the 2008 financial crisis and the European sovereign debt crisis due to weak integration of its financial system to global finance. Its economy experienced a relative slowdown due to the fall in oil and gas prices and economic recession in the main trading partners, in particular, European countries.

\section{Political, Legal and Ethical Perspectives}

On the political front, Algeria adopted a republican regime since independence in 1962. The president is the head of state and is elected by direct universal suffrage every five years. The constitution gives him a central role in the management of country issues. He has the power to appoint the Prime Minister and members of the government upon the proposal of the latter The Algerian parliament constituted of the Council of the Nation (the upper house) and the People's National Assembly (the lower house), examines laws proposals, vote on laws and control the government.

The independence of the judiciary system been announced by the Algerian constitution of 1989 and consecrated by the constitution of 1996. The judge is protected against all forms of pressures and only obeys the law. He is responsible only to the Higher Judicial Council chaired by the President of the Republic (Ministry of Justice). Algerian law is influenced by the French law and Muslim law. It comes from various sources: constitution, laws adopted by Parliament, decrees and ministerial orders, international treaties and conventions ratified by Algeria.

Algeria, by the law 07-11 of November 25th, 2007 on the financial and accounting system, abandoned the national accounting system which dates from 1975 to adopt a new system based on the IASB international standards (IFRS). The objective of this reform was to harmonize Algerian company's financial statements with internationally recognized standards and practices. This Act came into force on January 1st, 2009 (Ould \& Smail, 2011).

Rich in natural resources and economically stable, Algeria has attracted in recent years increasing FDI inflows, particularly in hydrocarbons sector, real estate and infrastructure development (roads, railways, ports, airports), telecommunications, tourism, banking etc.. To attract and encourage foreign investment, the government has introduced various attractive provisions in the form of tax benefits (tax exemptions ranging from 3 to 10 years). However, in the context of the complementary budget law of 2009, the government adopted a series of protectionist measures that go in the sense of restricting FDI. Indeed, since 2010 , the (49-51) rule limits to $49 \%$ the share a foreign investor can hold in the equity capital of a local company and the majority of the capital $(51 \%)$ must be held by local partners. To this, is added the slowness of the administrative procedures, the complexity of legislations including tax laws and difficulty in access to industrial land (Foreign Direct Investment in Algeria, 2014).

Since the early 2000s, the Algerian government adopted an expansionary fiscal policy through the introduction of three economic stimulus packages for which exceptional funding has been mobilized: a plan to support economic recovery (2001-2004), the complementary plan to support growth (2005-2009) and Five-Year Development Plan (2010-2014). The desired objectives were: to boost production and its diversification, to boost growth and employment, support for private investment, modernization of economic and social infrastructure (roads, buildings, etc.). However, the results remain modest in view of the large amount of public expenditure, the GDP growth rate continues to be drawn mainly by hydrocarbons sector. Algeria is still not managed to diversify its economy and establish a competitive industrialization at the international level; it has the difficulty in adopting an economy less dependent on hydrocarbons. Many experts believe that there's a lack of visibility in the economic policy of the government (Seddiki, 2013). 


\section{Small \& Medium-Sized Businesses (SMBs) Trend}

The development of small and medium-sized businesses (SMBs) is the basis of the development of any economy. It is considered as a source of richness, economic growth and job creation. In Algeria, as in all countries of the world, the creation and promotion of SMBs take an important place in the development process of its economy.

In Algeria, the SMBs are born from the end of the 1980s; before that date, this type of business played a secondary role in the Algerian economic development. In the context of a planned economy, the priority was given to public companies (state-owned enterprises), all policies and measures to assistance and development were concentrated in favor of these companies. It is only after the economic crisis that has followed the oil shock of 1986, the state has decided to liberalize the economy by promulgating the law 88-25 of July 19th, 1988 which has liberalized the volume of private investment and set up financial and fiscal incentives to encourage and develop the private sector. Permission to foreign investment was set up in 1990 by the law 90-10 on money and credit, and then by the decree 91-37 of February 19th, 1991 concerning the liberalization of foreign trade. The number of private enterprises reached 22,382 companies in 1992. The following year, the Algerian state has taken other encouragement and support measures for the SMBs, has set up a new framework for legislation and implemented economic recovery reforms such as the new code on investment promotion promulgated in October 5th, 1993. The privatization of public enterprises dictated by the IMF and the World Bank as part of the structural adjustment program imposed on Algeria to mitigate the consequences of the crisis and ensure the country's transition to a market economy, largely contributed to the development of the SMBs (Gharbi, 2011). Since 2000, the weight of SMBs has increased significantly, the number has more than doubled. Between 2000 and 2007, 212,120 companies were created as a result of the guidance law of 2001 on the promotion of SMBs. At the end of 2010, the number of SMBs has experienced a noticeable evolution totalizing 607,297 companies. By the end of the first half of 2013, the number of SMBs is estimated at 747,934 (Ministry of Industrial Development and Investment Promotion, 2014).

Algeria launched since 2000 two programs to upgrade SMBs; a program of industrial competitiveness conducted by the Ministry of Industry and a second program conducted jointly by the Ministry of SMBs and the European Union. Many institutions to promote, support and guidance for SMBs have been created with the aim to facilitate the creation of enterprises, addressing related weaknesses that hamper the survival and functioning of these enterprises (Chelil \& Sidimohamed, 2012). Under the five-year plan 2010-1014, the Ministry of Industry, SMBs and Investment Promotion has set up a national program to create a new network of SMBs and upgrading companies. The program is expecting to create at least 200,000 new businesses. It should be noted that Algeria aims to reach the number of 2 million competitive SMBs operating in the market by 2025
(Smati, 2012).

Despite significant progress achieved in the SMBs sector, the Algerian businesses continue to face obstacles and constraints, penalizing their performance and prevent from the emergence of a dense and competitive industrial fabric: the difficult access to different means of financing and guarantees, the difficult access to industrial land because of the complexity and administrative red tape, the complexity of some regulations and procedures, lack of supervision, monitoring, support and management of the creation of SMBs.

\section{References}

Bali, H. (1993). Inflation and Undevelopment in Algeria. OPU: Algiers, Algeria.

Chelil, A., \& Sidimohamed, A. (2012). SMBs in Algeria: Realities and Perspectives. Retrieved May 22, 2014. From http://fseg.univ-tlemcen.dz/larevue09/CHELIL\%20Abdelatif.pdf

CIA World Factbook. (2012). Countries by GDP. Retrieved May 22, 2014. From https://unw.cia.gov/library/publications/the-world-factbook/fields/2195.html

Foreign Direct Investment in Algeria (2014). Retrieved May 22, 2014. http://www.planet-expert.com/fr/pays/algerie/investissement-direct-etranger-ide

Gharbi, S. (2011). SME / SMI in Algeria: Inventory of Fixtures. Working Paper No. 238, Research Laboratory on Industry and Innovation. Retrieved May 22, 2014. http://riien.univ-littoral.fr/wp-content/uploads/2011/03/doc-238.pdf

La Direction (2013). Algeria economic Situation: 2012 Perspectives. Retrieved May 22, 2014. From http://www.tresor.economie.gouv.fr/File/339732

Ministry of Agriculture and Rural Development (2012). Agriculture Sector Situation Report. Retrieved May 22, 2014. http://uww.minagri.dz/pdf/Rapports/Rapport\%20sur\%20la\%20situation\%20du\%20secteur\%20agricole\%202006.pdf

Ministry of Industrial Development and Investment Promotion (2014). SMBs Statistics Information Bulletins. . Retrieved May 22, 2014. From http://www.mdipi.gov.dz/

National Office of Statistics (2014). Retrieved May 22, 2014. From www.ons.dz

Ould, A., \& Smail, A. (2011). The Accounting Standards in Algeria: Presentation of New Accounting and Financial System. Revue des Sciences Economiques et de Gestion n`10.

Pironet, Olivier (2006). Algeria: History Timeline», Le Monde Diplomatique. Retrieved May 22, 2014. http://www.monde-diplomatique.fr/mav/86/PIRONET/14100

Seddiki, M. (2013). Investment and Governance in Algeria: What Relationship? International Conference of March $11^{\text {th }}$ and $12^{\text {th }}, 2013$, Algeria: Setif 1 University.

Smati, S. (2012). Focus on the Development of SMBs. Liberté, October $24^{\text {th }}, 23-29$.

World Statistics (2013). Countries Area in $\mathrm{Km}^{2}$. Retrieved May 22, 2014. From www.statistiques-mondiales.com/superficie_decroissant.htm 